\title{
ASSESSMENT OF VITAMIN D THERAPY EFFECT ON INFLAMMATORY MARKERS IN PEDIATRIC PATIENTS WITH TYPE I DIABETIC
}

\author{
KADHIM ALI KADHIM ${ }^{1}$, LUBAB TAREK NAFEA ${ }^{1}$, GAITH ALI GASIM² ${ }^{2}$, ESRAA ABDUL-AL HAMEED ${ }^{3}$, \\ HAYDER A FAWZI*
}

\begin{abstract}
${ }^{1}$ Department of Clinical Pharmacy, College of Pharmacy, Al-Mustansiriyah University, Baghdad, Iraq. ${ }^{2}$ Department of Pharmacology, College of Pharmacy, Al-Mustansiriyah University, Baghdad, Iraq. ${ }^{3}$ Consultant Endocrinology F.I.C.M.S., Child Central Teaching Hospital, Baghdad, Iraq, ${ }^{4}$ Clinical Pharmacist, Baghdad Medical City, Baghdad, Iraq. Email: hayder.adnan2010@ierit.nahrainuniv.edu.iq
\end{abstract}

Received: 06 August 2018, Revised and Accepted: 14 September 2018

\begin{abstract}
Objective: The objective of this study is to estimate the effect of Vitamin $\mathrm{D}_{3}$ supplementation on endogenous Vitamin $\mathrm{D}_{3}$ level and inflammatory biomarkers in newly diagnosed pediatric patients.

Methods: The patients were given oral Vitamin $\mathrm{D}_{3}$, and they divided into three groups: The first group (25 healthy pediatrics), the second group ( 25 newly diagnosed pediatric patients) treated with daily insulin regimen only, and the third group (25 newly diagnosed pediatric patients) treated with Vitamin $\mathrm{D}_{3}$ (2000 IU/day) with daily insulin regimen; all patients were treated for 90 days; and blood samples were taken at baseline and after 45 days and 90 days of starting Vitamin $\mathrm{D}_{3}$ to assess its potential effect on the levels of Vitamin $\mathrm{D}$, serum calcium, serum alkaline phosphatase levels, and other inflammatory markers.
\end{abstract}

Results: The results of the current study showed that serum IL- $1 \beta$ significantly declined in patients receiving Vitamin $\mathrm{D}_{3}$, while serum Vitamin $\mathrm{D}_{3}$, serum calcium, and interleukins- 4 were significantly increased in patients receiving Vitamin $\mathrm{D}_{3}$.

Conclusion: Daily vitamin $\mathrm{D}_{3}$ in addition to insulin offers favourable immunological effect in paediatric patients with Type I DM.

Keywords: Type 1 diabetes mellitus, Vitamin $\mathrm{D}_{3}$, Interleukin-4, Interleukin-1 $\beta$.

(C) 2018 The Authors. Published by Innovare Academic Sciences Pvt Ltd. This is an open access article under the CC BY license (http://creativecommons. org/licenses/by/4. 0/) DOI: http://dx.doi.org/10.22159/ajpcr.2018.v11i10.28936

\section{INTRODUCTION}

Diabetes mellitus (DM) is a persistent hyperglycemia caused by defects in insulin secretion, insulin action, or both [1]. Vitamin D, known primarily as a hormone of bone metabolism, can affect the transcription of a number of genes. In addition, Vitamin D may inhibit the renin-angiotensin system, reduce parathyroid hormone levels, decrease coagulation, reduce inflammation thereby reducing atherosclerosis, and increase insulin production [2], and other study found an association with asthma [3]. This persistent hyperglycemia may lead to long-term damage and loss of functions of many organs [4]. Symptoms of hyperglycemia include polyuria, polydipsia, polyphagia, blurred vision, and decrease in weight and to less common are insufficient growth and increase exposure to infections [1,5]. Type 1 DM (T1DM) accounts for $5-10 \%$ of all cases of diabetes [6]. Genetic, environmental, and immunologic factors can cause the destruction of the pancreatic $\beta$-cells and insulin deficiency in T1DM, and mostly, this process results from autoimmune $\beta$-cell destruction, although not all cases have the evidence of islet directed autoimmunity [7].

Individuals with a genetic susceptibility have normal $\beta$-cell mass at birth but start to lose their $\beta$-cells secondary to the autoimmune destruction that may occur over months to years, and this autoimmune process is thought to be triggered effect and continuously progress through a $\beta$-cell-specific molecule. The disease becomes clinically clear after the development of immunologic markers in the presence of the stimulating event. After that, $\beta$-cell mass begins to decline or about $80 \%$ of $\beta$-cells are destroyed, and insulin secretion becomes gradually impaired, but the glucose tolerance remained normal [8]. In vitro study suggested that interleukin-1 (IL-1) and tumor necrosis factor, two cytokines mostly produced by macrophages, induce structural changes of $\beta$-cells and suppression of their insulin releasing ability [9]. The children were given 2000 IU of Vitamin D daily in early childhood associated with reduced risk of T1DM. However, the mechanism stilled unclear $[10,11]$. Studies on a systemic defect in immune regulation suggested that natural killer T-cells (NKTC) activity and antigen presenting cells (APC) function are all decreased in diabetic patients [12]. On the other hand, lack of NKTC activity also results in the fewer amount of IL-4 production and subsequently lower amount of APC activation than required to maintain the normal immunity functions [13]. Vitamin $\mathrm{D}_{3}$ influences the pathogenesis, risks, and complications of DM. Studies have shown that Vitamin $\mathrm{D}_{3}$ supplementation in infancy reduces the risk of developing T1DM later in early adulthood [14]. Vitamin $\mathrm{D}_{3}$ receptors have immunemodulating effects, and the development of T1DM may be associated with polymorphisms in the Vitamin D receptor gene $[15,16]$.

\section{METHODS}

This is a prospective randomized controlled open-label study carried out in Child Central Teaching Hospital in the outpatient clinic of the endocrinology department during the period from April 2015 to May 2016. The study was approved by the Ethics Committee by College of Pharmacy/University of Al-Mustansiriyah, and written informed consent was taken from all participants (their legal guardian since all of them are minors). The study was conducted on 50 newly diagnosed T1DM patients (with duration of disease $\leq 1$ year), and ages were between 4 and 12 years. The patients' records were kept for the next 3 months after their initial visit to the hospital; they were observed for Vitamin $\mathrm{D}_{3}$ that measured before and after 45 days and after 90 days of treatment. All the patients kept on similar management and dose of Vitamin $\mathrm{D}_{3}$, as well as their regular medications for DM. The patients were randomized into two groups: Group 1 with 
25 patients receive 2000 IU Vitamin $\mathrm{D}_{3}$ once daily only in addition to the normal insulin regimen and Group 2 with 25 patients receive insulin (soluble and lente) twice daily.

From all eligible subjects, demographic (age and gender) and laboratory markers (Vitamin D, ionized calcium, alkaline phosphatase [ALP], $\mathrm{IL}_{1 \beta}$, and $\mathrm{IL}_{4}$ ) were recorded at baseline and after 45 and 90 days for both the groups.

About $5 \mathrm{ml}$ of fasting venous blood collected and serum stored at $-20^{\circ} \mathrm{C}$ after separation, and this sample was used to assess the serum levels of fetal bovine serum, hemoglobinAlc, ionized calcium, ALP, Vitamin D, IL-1 $\beta$, and IL-4, as illustrated in Table 1.

\section{Statistical analysis}

Data were presented in simple measures of frequency, mean, and standard error. The significance of the difference of different means (quantitative data) was tested using students' t-test for the difference between two independent means or paired t-test for difference of paired observations (or two dependent means). The significance of the difference of different percentages (qualitative data) was tested using Pearson Chi-square test with application of Yate's correction or Fisher's exact test whenever applicable. SPSS version 20 (USA, Chicago, IL) software package was used for the statistical analysis. Statistical significance was considered whenever the $P$ value was $\leq .05$

\section{RESULTS}

There was no significant difference in age and gender between Groups 1 and 2 , as illustrated in Table 2 .

Serum Vitamin $\mathrm{D}_{3}$ was significantly higher in Group 1 compared to Group 2 after 45 and 90 days, and in Group 1, serum Vitamin $D_{3}$ increased from 45 to 90 days, but it was not statistically significant, while for Group 2, there was a significant reduction in serum Vitamin $\mathrm{D}_{3}$ from 45 days to 90 days. In Group 1 , serum $\mathrm{IL}_{1 \beta}$ significantly reduced after 90 days, while no significant change in Group 2 was observed. In Group 1, serum $\mathrm{IL}_{4}$ was significantly increased after 90 days, while in Group 2, there was a significant reduction in $\mathrm{IL}_{4}$ after 90 days, as illustrated in Table 3 .

There was no significant association between Vitamin D with inflammatory markers after supplementation of Vitamin D, as illustrated in Table 4

Table 1: List of various laboratory markers used in the study with its supplier

\begin{tabular}{ll}
\hline Suppliers & Diagnostic kit \\
\hline RANDOX, UK & Fasting blood glucose kit (manual), \\
& ELISA \\
Cobas 411 (ROCH), Germany & Insulin kit (auto-analyzer) \\
RANDOX, UK & Ca kit, ELISA \\
bioMerieux, France & ALP kit, ELISA \\
bioMerieux, France & Vitamin D3 kit, auto-analyzer \\
Bio-Rad, USA & HbA1c kit auto-analyzer \\
Elabscience, China & IL 1 $\beta$ kit, ELISA \\
Elabscience, China- & IL 4 kit, ELISA \\
\hline
\end{tabular}

ALP: Alkaline phosphatase, IL: Interleukin

Table 2: Demographic data of the patients

\begin{tabular}{llll}
\hline Variables & T1DM and Vitamin D & T1DM & p-value \\
\hline $\begin{array}{l}\text { Age (years) } \\
\text { Gender }\end{array}$ & $8.2 \pm 2.5$ & $8.8 \pm 2.6$ & 0.410 \\
Female & $17(68 \%)$ & $13(52 \%)$ & 0.248 \\
$\quad$ Male & $8(32 \%)$ & $12(48 \%)$ & \\
\hline
\end{tabular}

Data presented as mean \pm SD, T1DM: Type 1 diabetes mellitus

\section{DISCUSSION}

In the current study serum, $\mathrm{IL}_{1 \beta}$ was significantly decreased in patients receiving Vitamin $\mathrm{D}_{3}$ in addition to insulin while those who did not receive Vitamin $\mathrm{D}_{3}$ had a non-significant increase in $\mathrm{IL}_{1 \beta}$, and also, serum $\mathrm{IL}_{4}$ was significantly increased after 90 days for those receiving Vitamin $\mathrm{D}_{3}$ while those receiving insulin only had a significant decrease in $\mathrm{IL}_{4}$ serum levels.

It is understandable now that Vitamin D displays an anti-inflammatory effect as one of its major roles, and its deficiency is often accompanied with increased risk of any inflammatory, immunological, and autoimmune disorders. The active biological metabolite of Vitamin D [Vitamin D3] is a potent regulator of the immune response and functions by binding to the Vitamin D receptor with immunomodulatory properties [17].

Contact et al. study shows an inhibitory effect for Vitamin D3 on Th1 cell activation where these cells play an essential part in immune and inflammatory diseases by producing inflammatory cytokines, such as IL-1, and thus, Vitamin D3 plays an important key role in the inhibition, differentiation, and proliferation of both $\mathrm{T}$ and $\mathrm{B}$ cells, reduces polarity of $\mathrm{Th}_{0}$ cells to $\mathrm{Th}_{1}$ cells, and inhibits the generation and production of cytokines which leads to destruction of pancreatic islet cells and then induces endoplasmic reticulum stress and apoptosis by pro-inflammatory cytokine [18-20]. Furthermore, these cells produce Vitamin D3 which then regulates their proliferation and function [21].

Our findings were in agreement with Cantorna et al. study that production of the Th2-associated cytokine IL-4 could be upregulated by

Table 3: Assessment of various markers in pediatric patients with T1DM

\begin{tabular}{|c|c|c|c|}
\hline Variables & $\begin{array}{l}\text { T1DM and } \\
\text { vitamin D }\end{array}$ & T1DM & p-value \\
\hline \multicolumn{4}{|c|}{ Vitamin $\mathrm{D}_{3}(\mathrm{ng} / \mathrm{ml})$} \\
\hline Baseline & $11.05 \pm 0.992^{\mathrm{a}}$ & $15.0 \pm 1.565^{\mathrm{a}}$ & 0.038 \\
\hline After 45 days & $18.55 \pm 1.081^{\mathrm{b}}$ & $14.14 \pm 1.051^{\mathrm{a}}$ & 0.009 \\
\hline After 90 days & $26.41 \pm 1.796^{\mathrm{b}}$ & $10.52 \pm 0.808^{b}$ & $<0.001$ \\
\hline \multicolumn{4}{|c|}{ Calcium ionized (mmol/L) } \\
\hline Baseline & $1.56 \pm 0.089^{\mathrm{a}}$ & $1.76 \pm 0.093^{\mathrm{a}}$ & 0.127 \\
\hline After 45 days & $1.54 \pm 0.079^{\mathrm{a}}$ & $1.65 \pm 0.078^{\mathrm{b}}$ & 0.327 \\
\hline After 90 days & $1.74 \pm 0.089^{\mathrm{b}}$ & $1.50 \pm 0.076^{\mathrm{b}}$ & 0.046 \\
\hline \multicolumn{4}{|l|}{$\operatorname{ALP}(\mathrm{U} / \mathrm{L})$} \\
\hline Baseline & $291.2 \pm 26.613$ & $333.81 \pm 18.591$ & 0.196 \\
\hline After 45 days & $293.12 \pm 21.905$ & $327.82 \pm 20.429$ & 0.252 \\
\hline After 90 days & $306.80 \pm 20.027$ & $351.66 \pm 17.280$ & 0.096 \\
\hline \multicolumn{4}{|l|}{$\mathrm{IL}_{1 \beta}(\mathrm{pg} / \mathrm{ml})$} \\
\hline Baseline & $9.435 \pm 2.54^{\mathrm{a}}$ & $6.587 \pm 2.205^{\mathrm{a}}$ & 0.401 \\
\hline After 90 days & $3.017 \pm 0.452^{\mathrm{b}}$ & $11.731 \pm 4.316^{\mathrm{a}}$ & 0.049 \\
\hline \multicolumn{4}{|l|}{$\mathrm{IL}_{4}(\mathrm{pg} / \mathrm{ml})$} \\
\hline Baseline & $36.546 \pm 24.064^{\mathrm{a}}$ & $55.889 \pm 19.728^{a}$ & 0.537 \\
\hline After 90 days & $47.297 \pm 27.430^{\mathrm{b}}$ & $13.832 \pm 2.919^{\mathrm{b}}$ & 0.231 \\
\hline
\end{tabular}

Data were presented as mean \pm SEM similar letters within a columns

$(a, b$, and c) denote no significant difference between means; otherwise, they differ significantly $(\mathrm{p}<0.05)$, $\mathrm{IL}_{1 \beta}$ : Interleukin ${ }_{1 \beta}, \mathrm{IL}_{4}$ : Interleukin ${ }_{4}, \mathrm{ALP}$ : Alkaline phosphatase, T1DM: Type 1 diabetes mellitus, SEM: Standard error of the mean

Table 4: Association between vitamin D with inflammatory markers at baseline and after supplementation of vitamin D

\begin{tabular}{lllll}
\hline Markers & \multicolumn{2}{l}{ Serum vitamin D } \\
\cline { 2 - 5 } & \multicolumn{2}{l}{ Baseline } & \multicolumn{2}{l}{ After 90 days } \\
\cline { 2 - 5 } & $\mathbf{r}$ & p-value & $\mathbf{r}$ & p-value \\
\hline $\mathrm{IL}_{1 \beta}$ & -0.198 & 0.343 & -0.165 & 0.431 \\
$\mathrm{IL}_{4}$ & -0.017 & 0.936 & 0.022 & 0.919 \\
\hline r: Correlation coefficient, $\mathrm{IL}_{1 \beta}$ Interleukin $_{1 \beta}, \mathrm{IL}_{4}:$ Interleukin $_{4}$ &
\end{tabular}


Vitamin D3 treatment [22], also Vitamin D3 inhibited Th1 cell expansion and cytokine production and resulted in Th2 cell expansion and increased IL-4 production $[22,23]$ with promoting the Th2 cytokine production of IL-4, for that reason orientated T cell response towards Th2 dominance thus it increase the production of more anti-inflammatory Th 2 cytokines (IL3, IL4, IL5, IL10) and inhibits Th1 response activity seems to play a major role in the treatment of autoimmune diseases [24]. The present study compatible with Virtanen et al. studies showed that Vitamin D3 administration had been shown to increase IL-4 and improve Vitamin D3 that may make the clear deviation in the immune system, specifically in THC [25]. The role of regulation IL-4 production is controversial as Gregori et al. showed that the inhibition of both Th1 and Th2 cell cytokine production, including the inhibition of IL- 4 [which then may trigger humoral immunity leads to antibody production] [26].

\section{CONCLUSION}

Daily vitamin $\mathrm{D}_{3}$ in addition to insulin offers favourable immunological effect in paediatric patients with Type I DM.

\section{CONFLICTS OF INTEREST}

No financial, personal, or any other type of interest will present a conflict concerning this work.

\section{AUTHORS' CONTRIBUTIONS}

All authors contributed equally in this research.

\section{REFERENCES}

1. American Diabetes Association. Standards of medical care in diabetes-2011. Diabetes Care 2011;34 Suppl 1:S11-61.

2. Hallak A, Malhis M, Abajy MY. Vitamin-D deficiency and risk of acute coronary syndrome. Int J Pharm Pharm Sci 2018;10:171-5.

3. Abbas RS, Abdulridha MK, Shafek MA. Clinical evaluation of potential anti-inflammatory effect of Vitamin D3 adjuvant therapy for chronic asthma in iraqi patients. Int J Pharm Pharm Sci 2017;9:139-44.

4. Vlassara H, Palace M. Diabetes and advanced glycation endproducts. J Int Med 2002;251:87-101.

5. Hamid S, Sahib HB, Fawzi HA, Nori AY. Medication adherence and glycemic control in newly diagnosed diabetic patients. Int J Res Pharm Sci 2018;9:816-20

6. Deshpande AD, Harris-Hayes M, Schootman M. Epidemiology of diabetes and diabetes-related complications. Phys Ther 2008;88:1254-64.

7. Winer S, Tsui H, Lau A, Song A, Li X, Cheung RK, et al. Autoimmune islet destruction in spontaneous Type 1 diabetes is not $\beta$-cell exclusive. Nat Med 2003;9:198.

8. Atkinson MA. The pathogenesis and natural history of Type 1 diabetes.
Cold Spring Harb Perspect Med 2012;2:a007641.

9. Rabinovitch A, Suarez-Pinzon WL. Cytokines and their roles in pancreatic islet $\beta$-cell destruction and insulin-dependent diabetes mellitus. Biochem Pharmacol 1998;55:1139-49.

10. Hypponen E, Laara E, Reunanen A, Jarvelin MR, Virtanen SM. Intake of Vitamin D and risk of Type 1 diabetes: A birth-cohort study. Lancet 2001;358:1500-3.

11. Alizzi FJ, Abbas WA, Fawzi HA. Assessment of the role of cholecystokinin in hyperemesis gravidarum and correlation with its severity. J Pharm Sci Res 2018;10:272-5

12. Tard C, Rouxel O, Lehuen A. Regulatory role of natural killer T cells in diabetes. Biomed J 2015;38:484-95.

13. Adrian V, Romulus T. Pathogenesis of Type 1 diabetes mellitus: A brief overview. Rom J Diabetes Nutr Metab Dis 2012;19:67-72.

14. Mathieu C, van Etten E, Decallonne B, Guilietti A, Gysemans C, Bouillon R, et al. Vitamin D and 1, 25-dihydroxy Vitamin D3 as modulators in the immune system. J Steroid Biochem Mol Biol 2004;89-90:449-52.

15. Palomer X, Gonzalez-Clemente JM, Blanco-Vaca F, Mauricio D. Role of Vitamin D in the pathogenesis of Type 2 diabetes mellitus. Diabetes Obes Metab 2008;10:185-97.

16. Lemire J. 1, 25-Dihydroxy Vitamin D3--a hormone with immunomodulatory properties. Z Rheumatol 2000;59 Suppl 1:24-7.

17. Goswami R, Mishra SK, Kochupillai N. Prevalence and potential significance of Vitamin D deficiency in Asian Indians. Indian J Med Res 2008;127:229-38

18. Szodoray P, Nakken B, Gaal J, Jonsson R, Szegedi A, Zold E, et al. The complex role of Vitamin D in autoimmune diseases. Scand J Immunol 2008;68:261-9.

19. Conti P, Kempuraj D. Impact of Vitamin D on mast cell activity, immunity and inflammation. J Food Nutr Res 2016;4:33-9.

20. Harinarayan CV. Vitamin D and diabetes mellitus. Hormones Athens 2014;13:163-81.

21. Al Homsi M, Lukic M. An Update on the Pathogenesis of Diabetes Mellitus. Al Ain, United Arab Emirates: Department of Pathology and Medical Microbiology (Immunology Unit) Faculty of Medicine and Health Sciences, UAE University, 1992.

22. Cantorna MT, Mahon BD. Mounting evidence for Vitamin D as an environmental factor affecting autoimmune disease prevalence. Exp Biol Med (Maywood, NJ) 2004;229:1136-42

23. Zella JB, De Luca HF. Vitamin D and autoimmune diabetes. J Cell Biochem 2003;88:216-22.

24. Baeke F, Takiishi T, Korf H, Gysemans C, Mathieu C. Vitamin D: Modulator of the immune system. Curr Opin Pharmacol 2010;10:482-96.

25. Virtanen SM, Knip M. Nutritional risk predictors of beta cell autoimmunity and Type 1 diabetes at a young age. Am J Clin Nutr 2003;78:1053-67.

26. Gregori S, Giarratana N, Smiroldo S, Uskokovic M, Adorini L. A 1alpha, 25-dihydroxyvitamin $\mathrm{D}(3)$ analog enhances regulatory T-cells and arrests autoimmune diabetes in NOD mice. Diabetes 2002;51:1367-74. 